\title{
18. Styles of Conservative Leadership in Australian Politics
}

\section{Wayne Errington}

\section{Introduction}

Contemporary political science literature on leadership has sought, primarily, to understand policy innovation and the achievement of goals. For Robert Tucker (1987: 15), political leadership is the act of giving direction to a group or community. Blondel (1987: 25) sees political leadership as action designed to modify the environment. By these measures, leadership is not so much a journey or a relationship as a changing of the social and political landscape for which leaders are the overseers and instigators. Goal-centred approaches to leadership seek to differentiate leadership from office-holding; judging leaders by measuring stated goals against achievements. This interest in the way in which leaders go about achieving their goals has been influenced by management studies (Peele 2005: 188). Yet, conservative leaders tend to be measured by their electoral success rather than their legislative achievements. Conservative leaders can still be measured by their attainment of goals, but the goals of conservative and progressive leaders differ quite markedly. The relationship between leader and followers is a complex one if the goals of the leader are not clear-cut.

Since Weber, the notion of charisma - and personality types more generally has never been far from the study of leadership. Social psychology has reminded political science that leaders are not simply cogs in the societal mechanism. Burns divided leaders into those with transformational or transactional styles. Again, some notion of goal-setting seems to be explicit since, to Burns, leadership is 'intended change' (1974: 434). More grounded in the experience of conservative leaders is Little's formulation of strong leadership (1988). Strong leadership can lend itself to transformation or to national defence in the face of real or perceived threats. Yet, conservative leadership may be better understood when process-centred accounts of leadership are utilised. Post, for example, stresses the 'mutual purposes' that leaders and followers perceive in their relationship (1991: 102). Indeed, successful leaders tend to be those who can mobilise followers around a set of ideas, rather than simply a set of goals (see Folkertsma 1988).

Conservative leaders tend to defy the labels of leadership theorists or, more to the point, they might suit any of these labels at any given time. Modern political history, particularly in the Anglo-Saxon world, is replete with examples of conservative governments that were activist legislators - self-conscious agents of change. These reformist conservative governments came about for a number 
of reasons. They had the opportunity (they would argue the duty) to change long-held social compacts within which previous conservative governments had operated. Their opportunities came about because of real and perceived economic problems for which a range of conservative leaders proposed market-oriented solutions. In this environment, conservatives with political ambition promote policy innovation in order to bring notice to themselves and underline their leadership qualities. This is sometimes referred to as 'policy entrepreneurship' (see Mackenzie 2004).

The environment in which leaders govern, then, is crucial to our understanding of both their goals and methods. An economic crisis might convince conservatives that the only way to preserve the social arrangements they value is through policy innovation. This chapter seeks to examine a range of environments and leadership styles that might be appropriate to conservative leaders. It establishes a typology of leadership styles by taking into account goals incorporating, but not limited to, public policy. Those leadership styles are then applied to a number of Australian conservative prime ministers, with the primary focus on the most recent - John Howard.

\section{Making room for conservative leadership}

Richardson, Gustafsson and Jordan developed a typology of national policy styles, highlighting a 'consensus' versus 'imposition' approach to implementation on one axis, and an 'anticipatory' versus 'reactive' type of problem-solving on the other axis (1982: 13). These policy styles were adapted by Barton and van Onselen (2004) to leadership styles in Australia, plotting the differences between Australian state premiers Jeff Kennett and Richard Court. Naturally, an impositional style of leadership (that attributed to Kennett by Barton and van Onselen) lends itself to the change-oriented approaches to leadership outlined earlier. One might interpret the more radical style of a Kennett as a desire to maintain a capitalist mode of production. A distinction between classical liberal and conservative goals is nevertheless worth preserving. Either way, leadership literature dealing with goal-oriented policy change can accommodate a style of conservative leadership that sets and achieves policy goals. Other aspects of conservative leadership, though, are not so well served by the dominant paradigm in leadership studies.

Moon (1995), seeking to explain the success of British Prime Minister Margaret Thatcher, developed the concept of innovative leadership to describe leaders with both strong political will and a strong policy capacity (the right environment for change). How, though, do such typologies deal with the conservative leader whose primary goal is to hold office? For Moon, the opposite of innovative leadership is inertia. This might be an apt description of many a political leader, but Moon's typology does not account for a leader whose goals are not specifically policy-oriented. A successful conservative politician such as long-serving 
Australian Prime Minister Robert Menzies can hardly be said to have lacked either political will or policy capacity. Yet, Menzies only occasionally sought to be an innovative policy leader as Prime Minister (with a few exceptions, such as extending Commonwealth grants to Catholic schools). Menzies's achievement in fashioning a successful conservative party where others had failed and holding power for 17 years was an impressive feat of leadership.

Achievement of conservative goals, then, may take a good deal of leadership skill. The goals of conservative leaders are not always clear-cut. Successful conservative leaders are adaptive. If they hold office for an extended period, we might expect them to appear in various places on the various diagrams produced by scholars of leadership, depending on the time and the issue in question. Retaining the status quo while being buffeted by exogenous forces such as globalisation, or during a national crisis or disaster, is a feat of leadership too often ignored by the change-merchants. Leadership during a crisis presents an opportunity for a different set of relationships between leaders and followers. Heifetz argues that citizens in democracies too often respond to crises by turning to leaders who offer strength and easy answers rather than those who offer the right leadership qualities to find and implement solutions (1994: 2). A number of Australian conservative leaders have been analysed through the notion of strong leadership. Strong leadership could conceivably be brought to the service of radical goals, but the psychological dimension of this leadership style has been more often associated with the bond between conservatives and their followers.

A simple typology (Table 1) combining the radical or conservative ends of leadership with the impositional or consensus styles described above produces four leadership styles - transformative, strong, reassuring, and conservatorship. The notion of radical or conservative ends does not preclude a range of policy orientations depending on the environment. Strong leadership, for example, might entail stringency measures meant to preserve a set of institutions thought to be under threat (during a war or other crisis) or a set of more radical policies aimed at preserving the social status quo through a new policy orientation (in response to globalisation or declining terms of trade). Conservatorship acknowledges the lack of policy innovation that often defines conservative government without conceding that the political activity involved in the preservation of social institutions does not involve considerable leadership challenges.

\section{Table 1: Goals and methods in political leadership}

\begin{tabular}{l|c|c}
\hline & \multicolumn{2}{|c}{ Goals } \\
\hline Methods & Radical & Conservative \\
\hline Imposition & Transformational leadership & Strong leadership \\
\hline Consensus & Reassuring leadership & Conservatorship \\
\hline
\end{tabular}


The notion of transformational leadership is probably the most familiar to scholars of leadership. Combining radical ends with an uncompromising leadership style, transformative leaders run the risk of moving too far ahead of their followers. Kennett sought and failed to be a transformative leader: one with more liberal than conservative goals. However, his failure to win the 1999 Victorian election was a sign that he suffered the fate of many strong leaders: failing to adapt his leadership style to changed circumstance. As the sense of economic crisis that Kennett had exploited faded into the distance, voters turned to the more reassuring leadership style of Labor's Steve Bracks.

\section{Contemporary Australian conservative leadership}

While Menzies's astonishing record of office-holding success makes him the touchstone of Australian conservative leadership, the environment in which he governed was a largely benign one. His conservatorship was suited to the post-war Keynsian economic management - occupying the political centre ground and painting his opponents as radicals. Mindful of the previous conservative government's failure to win popular support for laissez-faire policies and by disposition suspicious of the business lobbies, Menzies used his multiple election victories to win only modest policy changes. The more challenging economic environment of the 1970s was the appropriate environment for a quite different style of leadership exercised by Malcolm Fraser. While the liberal elements of Fraser's ideology have been on display since his retirement from the prime ministership, his relationship with the electorate was based on a willingness to take tough decisions in difficult times. Cuts to expenditure, calls for wage restraint and traditional conservative rhetoric on national security made Fraser an archetypal strong leader (Little 1988).

The Fraser government's failure to reform the Australian economy subsequently became the subject of division within the Liberal Party. While Fraser toyed with monetarism in response to rising inflation (in line with similar efforts elsewhere in the developed world), the ideas that later governments would implement in response to Australia's declining economic fortunes were undeveloped during Fraser's tenure as Prime Minister. Fraser's view of Australia's economic problems was that while difficult decisions were required, the policy prescriptions necessary were those familiar to conservative governments since the end of the war. Strong leadership aimed at radical policy change is a risky political strategy and, therefore, relatively rare. Thatcher's example requires the combination of unusual circumstances and personality types.

One Australian who admired Thatcher's success was Fraser's treasurer, John Howard. As the Labor governments of Hawke and Keating took the difficult decisions to transform the Australian economy (employing the unique combination of Keating's zeal and Hawke's reassurance), Howard battled for supremacy inside the Liberal Party. 
Howard started his political career as an unquestioning Menzian, suspicious of change and reform. It was the difficult economic circumstances of the 1970s that caused Howard to question Keynesian economic policy. Howard's conversion to what was fast becoming the neo-liberal orthodoxy coincided with his interest in positioning himself as a successor to Fraser. Howard began to style himself as a reformer during the third term of the Fraser government. He ran into resistance in cabinet for his proposals to deregulate the financial system. Adjusting his policy orientation over the course of his career, Howard constructed an approach to government that defies simple descriptions or labels, and utilised at least two of the leadership styles described in this chapter. He differentiated himself from his major competitor for the Liberal leadership in the 1980s, Andrew Peacock, by advocating policy change more radical than the Hawke government was putting in place. This earned Howard the admiration of many in the press gallery. Promoting reform from opposition, though, proved to be difficult. During his first stint as opposition leader (1985-89), Howard was ahead of both the Hawke government and public opinion on issues of deregulation.

Another of the unsuccessful Liberal leaders during the Hawke-Keating years, Dr John Hewson, took the ideas of liberal transformation of Australian society to its zenith with his Fightback package. Unlike most Liberal Party members, Hewson was socially as well as economically liberal. While the recession of the early 1990s should have been ripe for a change of government, the public could not connect with Hewson on any level. His classical liberalism was shared by few voters. His technocratic style lacked the psychological elements of strong leadership that others may have brought to bear in those circumstances. In stark contrast to Hewson, upon his return to the Liberal Party leadership in 1995, Howard attempted to take advantage of the 'reform fatigue' in the electorate.

Conservative by disposition and mindful of the success of Menzies's conservatorship, Howard disappointed many of his most zealous supporters with the caution of his first two terms. The paradox at the heart of John Howard's leadership was his ability to profit from the electorate's fear of change while continually advocating (if not actually delivering) economic reform. He was assisted in this by an environment conducive to strong leadership, especially after the September 11, 2001 terrorist attacks on the United States. While Howard had long since distanced himself ideologically from Fraser, he was a close witness to the effectiveness of Fraser's strong leadership in winning the prime ministership and on issues of national security.

One of Howard's strengths as a communicator was to simultaneously provide reassurance and persuasion. His continual use of talkback radio to justify government policies was a new dimension in Australian politics. The majority of Australians had yet to be convinced that the market-oriented reforms of the last two decades were a good idea. Howard's reply to a journalist's question 
about his vision for Australia - that he wanted Australians to be 'comfortable and relaxed' summarised the Coalition strategy for the 1996 election.

The Howard Government was the most active legislator in Commonwealth history. This would seem to mark Howard with a different leadership style than Menzies. However, a more active legislature is part of a response to the different government environment that contemporary leaders face. By 1996, the broadsheet press, the public service, both major political parties, and state governments were well versed in making and selling to the public difficult economic and social policy decisions. During and after the 2001 election campaign, Prime Minister Howard was asked one question more than any other: the press gallery wanted to know what his third term agenda was? Similar questions bugged him on the campaign trail in 2004. This constant refrain says something about the expectations of contemporary leaders. Howard's skill in dealing with some of the modern elements of politics - most notably the era of globalisation in which most of his leadership career took place and the demands of the 24-hour media cycle - confounded those critics who assumed that social conservatism was all that there was to his political outlook. It may be counter-intuitive to suggest that a conservative leader was so successful in setting the policy agenda, but Howard - backed by the public relations apparatus of the state - was as successful at this task as any Australian Prime Minister.

Howard's conservatism is underlined by the choices he made as Prime Minister. He was true to those elements of his reform agenda that serve political as well as economic ends - privatisation and labour market reform. His goal with these policies was to undermine social sources of support for the Australian Labor Party. Cuts in public spending, on the other hand, caused the government headaches in this first term for no great economic gain. After 1997, Howard made no serious attempt to rein in public spending. Howard's political goals were about winning - not just keeping Labor out of power but winning battles within his party as well. The extent to which Howard actually believed in the free-market policies he advocated from the 1980s is beside the point. They were only ever a means to an end - making the conservative parties electorally competitive in a changing world.

Howard's reassuring style in his first two terms was assisted by the fact that most of his closest followers had retired by the time he won office in 1996 (or, in the case of Michael Baume, quickly shunted to a diplomatic post instead of a ministry). He could dispassionately assess his own goals and the needs of national governance with fewer demands than the average prime minister to reward allies. His most important attribute in his second stint as opposition leader in stark contrast to the first - was his ability to reassure key sections of the community that he would take their interests into account when framing policy. The reduction in the immigration intake, his message that Australian history 
and nationalism was a source of pride, and his willingness to compromise over key elements of his economic program such as privatisation and the Goods and Services Tax all saw Howard treading a difficult path between the demands of elite groups and the voters that Howard saw as crucial to his electoral survival. His stances alienated almost as many constituencies as they impressed, of course, but that is the nature of democratic politics.

On the policy front, then, Howard was selective in the achievement of his goals, subordinate as they always were to his essentially conservative view of Australian politics. His political mission in life was to keep Labor off the treasury benches. He was able to win four elections by keeping up a balance between reassurance and advocacy of further reform. Adherence to the policy orthodoxy of Hawke and Keating (including policies he had earlier opposed, such as Medicare) was important to Howard's relationship with sections of the policy community and the media.

Howard's reassuring style was sufficient to win him the 1996 and 1998 elections, and to stage a comeback from disastrous opinion polling throughout 2001. That comeback depended, in part, in Howard's behaviour during and after the twin events that dominated the 2001 campaign - asylum seekers and the US terrorist attacks. Strong leaders respond to a difficult governing environment. Walter argues that Howard fits the 'strong leader' type due to the uncompromising way he approached factional politics in the Liberal Party, his firm position on social and cultural issues as Prime Minister, and the suitability of his political persona to the 'securitisation' agenda post-11 September 2001 (Walter 2006: 3-4). The first two of these elements of Howard's strong leadership had been in place for some time and did not translate into public perceptions of leadership strength.

In his first two terms, where other senior ministers urged him to take policy packages to a double dissolution election, Howard was satisfied with compromise (Errington and van Onselen 2007: 283). Labor Party advertisements during the 1996 election campaign contrasted public perceptions of Keating's leadership strength with the supposed weakness of Howard. The occasion on which public perceptions of Howard's leadership strength increased dramatically was in the midst of the Tampa affair, where Howard did something that the majority of the public wanted him to do - get tough on asylum seekers. Perceptions of strength were then reinforced by the hostility with which Howard's actions were met in sections of the intelligensia. Until late 2001, one of the characteristics of Howard's prime ministership had been his self-conscious courting of public opinion. Policy 'backflips' were a staple, not an exception, to Howard's strategy. Indeed, the comeback in the opinion polls throughout 2001 was dependent on a number of policy reversals on taxation and welfare policy. It was the 2001 election campaign that crystallised the leadership style that Howard would portray in his final three election contests. His command of the Liberal Party and combative social 
agenda by that point complemented his leadership style whereas they had caused him problems earlier in this career. It is much easier to be a strong leader as Prime Minister than it is as Leader of the Opposition.

Winning (notional) control of the Senate from 2005 caused Howard to reassess his approach to economic reform. Howard's political success was at its height when his government was forced to compromise with the Senate. Once Howard's leadership was unchallenged by the Senate, Howard felt obliged to live up to the reformist persona he had created over two decades. It was when circumstances allowed Howard to move to an impositional style of leadership that he lost public favour. Whatever the Australian public thought of Howard's strong leadership style on issues of national security, they had no interest in it when it affected in substance an issue close to their daily lives.

We see in John Howard many of the characteristics that political scientists have identified as crucial to our understanding of leadership: he is a fundamentally competitive human being; he liked to win; he enjoyed the tag of strong leader; and he was Prime Minister during a period in which the style (if not always the substance) of strong leadership was valued by the public. However, maintaining a persona of strong leadership would have prevented Howard from fulfilling other political goals. In spite of his protestations that the electorate knew Howard and could take him or leave him, Howard was not prepared to have the electorate judge him on his leadership strengths alone. He was too much of a transactional politician for that. Policy backflips, payoffs to key groups of followers, and compromise was as much a part of Howard's leadership style as strong leadership. Conservative leaders adapt to the times in which they govern. Howard governed in an age of reform and adapted accordingly. He stood firm when it suited, compromised when he had to, and reassured at every step of the way. However, once the strong leader persona came to define him in domestic as well as foreign policy terms, a reassuring Leader of the Opposition was able to defeat him at the 2007 election.

\section{Conclusion}

Contemporary Liberal Party leaders judge their success by the founder of their party, Sir Robert Menzies. John Howard looked upon Menzies as his political hero and distanced himself ideologically from the policies of his former boss Malcolm Fraser. Menzies and Fraser embody two important conservative leadership styles - respectively, conservatorship and strong leader. Whatever Howard thought of Fraser's policies, he often sought to portray himself in the strong leader style. Howard was too cautious, though, to govern in that style for his first two terms. Had he kept the mantle of conservator, he may still be Prime Minister. 
It may be another conservator who grabs the Menzies mantle next. The fate of Howard's strong leadership may convince future Liberal Party leaders that a style more in tune with popular concerns might be more effective. A nation weary of constant change may look for stability. Alternatively, problems such as global warming may set the stage for another strong leader. In any event, a successful conservative leader will set and achieve goals. Success will be measured by an ability to build and maintain political relationships as much as an ability to achieve lasting policy change. That often involves tailoring leadership style to a changing political environment.

\section{References}

Barton, Stephen and Peter van Onselen, 2004, 'Comparing Court and Kennett Leadership Styles: Energy Sector Reform in Victoria and Western Australia', Policy and Society, 22:2, p. 120-43.

Blondel, Jean, 1987, Political Leadership: Towards a General Analysis, London: Sage Publications.

Burns, James MacGregor., 1974, Leadership, New York: Harper and Row.

Errington, Wayne and Peter van Onselen, 2007, John Winston Howard: The Biography, Carlton: Melbourne University Press.

Folkertsma, Marvin, 1988, Ideology and Leadership, Englewood Cliffs: Prentice Hall.

Goldfinch, Shaun and Paul 't Hart, 2003, 'Leadership and Institutional Reform: Engineering Macroeconomic Policy Change in Australia', in Governance, 16:2, pp. 235-70.

Heifitz, Ronald, 1994, Leadership Without Easy Answers, New Haven: Harvard University Press.

Little, Graham, 1988, Strong Leadership: Thatcher, Reagan and an Eminent Person, Melbourne: Oxford University Press.

Mackenzie, C, 2004, 'Policy Entrepreneurship in Australia: A Conceptual Review and Application,' in Australian Journal of Political Science, 39:2, pp. 367-386.

Moon, Jeremy, 1995, 'Innovative Leadership and Policy Change: Lessons From Thatcher', in Governance, 8:1, pp. 1-25.

Peele, Gillian, 2005, 'Leadership and Politics: A Case for a Closer Relationship?' in Leadership, 1:1, pp. 187-204.

Post, Joseph C., 1991, Leadership for the 21st Century, New York: Praeger. 
Public Leadership-Perspectives and Practices

Richardson, Jeremy, Gunnel Gustafsson and Grant Jordan, 1982, 'The Concept of Policy Style', in J. Richardson (ed.), Policy Styles in Western Europe, Boston: Allen and Unwin.

Tucker, Robert, 1987, Politics as Leadership, London: University of Missouri Press.

Walter, James, 2006, 'John Howard and the "Strong Leader" thesis', paper presented to the John Howard's Decade Conference, Canberra, March. 